\title{
Identification of Pratylenchus penetrans (CoBB) by PCR Using ITS-Based Species-Specific Primers
}

\author{
Taketo Uehara ${ }^{1}$, Takayuki MizukuBO ${ }^{2}$, Atsuhiko Kushida ${ }^{1}$ \\ and Yoji Momota ${ }^{1}$
}

\begin{abstract}
For identifying Pratylencus penetrans, species-specific primers (PP1 and PP2) were developed, based on the sequences of the interscribed spacer regions (ITS1 and ITS2) of the rDNA. When the purified DNA from seven Pratylenchus species was subjected to PCR using these primers, the $462 \mathrm{bp}$ fragment was generated only for $P$. penetrans. The same fragment was obtained with DNA from the crude lysate of single juvenile and of adult (male and female) $P$. penetrans.
\end{abstract}

Jpn. J. Nematol. 28(1/2), 1-7 (1998).

Key words: identification, ITS-rDNA, PCR, Pratylenchus penetrans.

Among all Pratylenchus species inhabiting in Japan (19), P. penetrans is one of the most important root lesion nematodes, and damages roots of many plants $(5,7)$. Namely, it is a major pest of radish, carrot, burdock, lettuce, butterbur, and strawberry. The nematode-induced primary damage is a death of plant root cells around the nematodes, leading to a local lesion formation. Stunting, chlorosis, root pruning, and sparseness are successive symptoms (12).

For a successful management of nematode pests, a rapid and reliable identification of the causal species is critically important. Although a nematode identification is primarily based on morphological characteristics, it is difficult even for taxonomists due to variations in diagnostic features.

Isozyme analysis has been used to distinguish some Pratylenchus species (11), but it requires a large amount of nematode homogenate. Therefore, it is not suitable for nematode identification at organismic level. Using species-specific DNA probes, dot-blot analysis has been used to identify such nematodes as Globodera $(2)$, Meloidogyne $(1,16)$ and Bursaphelenchus, but it is timeconsuming and requires radioactive detection facilities.

The development of polymerase chain reaction (PCR) technology opened a way to a plant pathogen diagnosis (8). In this paper, we report newly developed P. penetrans-specific primers which based on the internal transcribed spacer (ITS) regions of the rDNA.

${ }^{1}$ Laboratory of Plant Nematology, Hokkaido National Agricultural Experiment Station, Hitsujigaoka-1, Toyohira-ku, Sapporo 062-8555, Japan.

${ }^{2}$ Laboratory of Plant Nematology, Kyushu National Agricultural Experiment Station, Suya 2412, Nishigoshi, Kikuchi-gun, Kumamoto, 861-1192, Japan. 


\section{MATERIALS AND METHODS}

\section{Nematode}

Pratylenchus penetrans, P. coffeae, P. vulnus, P. loosi, P. brachyurus, P. zeae, and P. crenatus were used. These nematodes were isolated from different geographical locations and hosts (Table 1). They were monoxenically maintained on alfalfa callus on Krusberg medium (15) and active nematodes were harvested by the Baermann-funnel method.

\section{DNA extraction}

Nematodes were crushed with mortar and pestle and then incubated at $37^{\circ} \mathrm{C}$ for $3 \mathrm{~h}$ in $200 \mu 1$ of extraction buffer (10 mM Tris-HCl: pH 8.0, $10 \mathrm{mM}$ EDTA, $100 \mathrm{mM} \mathrm{NaCl}, 0.5 \%$ SDS, and 200 $\mu \mathrm{g} / \mathrm{ml}$ proteinase $\mathrm{K})$. The lysate thus obtained was extracted with phenol/chloroform/isoamyl alcohol (25: 24: 1) (17). Nucleic acids were precipitated with ethanol and then dissolved in TE buffer (10 mM Tris-HCl: pH 8.0, 1 mM EDTA).

The crude lysates were also prepared by crushing a single juvenile or adult nematode with a needle in $15 \mu \mathrm{l}$ of lysis buffer ( $50 \mathrm{mM} \mathrm{KCl}, 10 \mathrm{mM}$ Tris- $\mathrm{HCl}: \mathrm{pH}$ 8.0, $2.5 \mathrm{mM} \mathrm{MgCl}, 60 \mu \mathrm{g} / \mathrm{ml}$ proteinase K, $0.45 \%$ NP $40,0.45 \%$ Tween 20 , and $0.01 \%$ gelatin) (3). The lysate was incubated at $65^{\circ} \mathrm{C}$ for $1 \mathrm{~h}$ and then at $95^{\circ} \mathrm{C}$ for $10 \mathrm{~min}$.

PCR

The ITS1 region of the rDNA was amplified using the 18S primer (5'-TTGATTACGTCCCT-

Table 1. Pratylenchus populations used in a PCR specificity test using the newly developed primers PP1 and PP2.

\begin{tabular}{lllll}
\hline Species & Code & Location & Host & PCR* \\
\hline$P$. penetrans & PH1 & Hokkaido & Carrot & + \\
$P$. penetrans & PH2 & Hokkaido & Soybean & + \\
$P$. penetrans & PI & Ibaraki & Radish & + \\
$P$. penetrans & PC & Chiba & Carrot & + \\
$P$. penetrans & PA & Aichi & Cabbage & + \\
$P$. penetrans & PH & Hyougo & Radish & + \\
$P$. penetrans & PS & Saga & Japanese iris & + \\
$P$. coffeae & CI & Ibaraki & Taro & - \\
$P$. coffeae & CN & Nagasaki & Taro & - \\
$P$. coffeae & CKU & Kumamoto & Buckwheat & - \\
$P$. coffeae & CKA & Kagoshima & Taro & - \\
$P$. vulnus & VSA & Saitama & Strawberry & - \\
$P$. vulnus & VS1 & Saga & Strawberry & - \\
$P$. vulnus & VS2 & Saga & Strawberry & - \\
$P$. loosi & LS1 & Shizuoka & Tea & - \\
$P$. loosi & LS2 & Shizuoka & Tea & - \\
$P$. brachyurus & BO & Okinawa & Prunus campanulata & - \\
$P$. crenatus & CH1 & Hokkaido & Soybean & - \\
$P$. crenatus & CH2 & Hokkaido & Carrot & - \\
$P$. zeae & ZK & Kagoshima & Sugarcane & - \\
$P$. zeae & ZO & Okinawa & Rhodesgrass & - \\
\hline+ : fragment & & & - \\
\hline
\end{tabular}

* + : fragment positive

- : fragment negative 
GCCCTTT-3') (23) and the 5.8S R primer (5'-ACGAGCCGAGTGATCCACCG-3'). The ITS2 region of the rDNA was amplified using the $5.8 \mathrm{~S}$ F primer (5'-CGGTGGATCACTCGGCTCGT$3^{\prime}$ ) and the $26 \mathrm{~S}$ primer (5'-TTTCACTCGCCGTTACTAAGG-3') (23). The $5.8 \mathrm{~S} \mathrm{R}$ primer and 5.8S F primer were constructed based on the 5.8S rRNA gene of Heterodera avenae (6). PCR was performed in a $25 \mu \mathrm{l}$ reaction mix containing about $20 \mathrm{ng}$ of DNA or $5 \mu \mathrm{l}$ of crude lysate, 1 unit of AmpliTaq Gold (Perkin-Elmer), $0.2 \mathrm{mM}$ dNTPS, $0.2 \mu \mathrm{M}$ of each primer, and $1 \times$ reaction buffer (10 mM Tris-HCl: $\mathrm{pH} 8.3,50 \mathrm{mM} \mathrm{KCl}, 1.5 \mathrm{mM} \mathrm{MgCl}_{2}$ ). PCR was performed in a PerkinElmer 2400 thermal cycler. An initial preincubation step at $95^{\circ} \mathrm{C}$ for 12 min was followed by 45 cycles of denaturation at $94^{\circ} \mathrm{C}$ for $45 \mathrm{~s}$, annealing at $50^{\circ} \mathrm{C}$ for $1 \mathrm{~min}$, and extension at $72^{\circ} \mathrm{C}$ for 1 $\min$. The final extension step was for $7 \mathrm{~min}$ at $72^{\circ} \mathrm{C}$. Then, 3 to $10 \mu 1$ aliquots of the PCR products were electrophoresed in $1.0 \%$ agarose gel, stained with ethidium bromide, and visualized with UV light.

\section{Cloning PCR amplified ITS fragments and DNA sequencing}

The plasmid pUC119 was cut with Hinc II to yield blunt ends, and then treated with Taq polymerase and dTTP for T-A overhang cloning (18). Amplified DNA was cloned into the pUC119-T vector using T4 DNA ligase, transformed into E. coli JM109 cells, and selected on

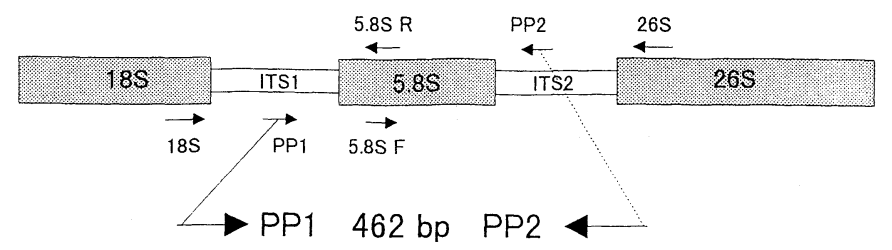

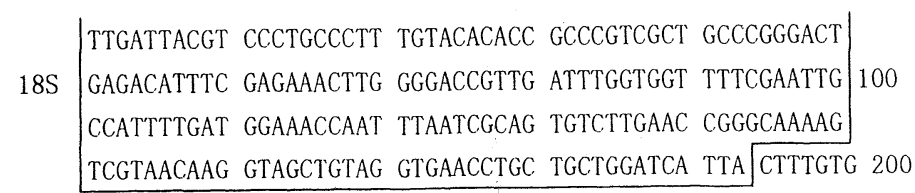

AGTAATGCTC AAATTTTTTT GACTATATGA CACATTTGAA CTTGACTCTC

ATAACATCAT ATCTGGTAAT GATGGAAGTG TCCGCCCTGA GGGGTGAACG 300

ITS1 GCTTCTGCTG GCGTCTGTGT CTTGTTGAGC AATTGTATTC CGTCCGTGGT

TGCTATGAGA CAAACGGTAG GACCCCATCC AAATATGCCT CAGGATGTGT 400

GGTTTAAGAC TTAATGAGCC CAATGCCTCA GGGCCGCCAG CATTTCTTTT

TTCTATTACA CTTTTTAAAC ACATGAAAGA ATT CTAGTCT TATCGGTGGA 500

TCACTCGGCT CGTGGTTCGA TGAAGAACGC AGCTAACTGC GATAAATAGT

5. 8S GCGAACTGCA GAAACATTGA GCACAAAAGC TTCGAATGCA CATTGCGCCA 600

TTGGAGTCAC TTCCTATGGC ACGCCTGGTT CAGGGTCATT A TCAAACAAA

AAACACAAAT GTGTGTTGTG AAATATATAA TCAATATCAT GTTTATATAT 700

ITS2 CGAGAATATC CCATTTTGAC CGTCGTTGGG ATTGATTCAA AATAACTATT

GGTCTGAAAG TTATTTTAAC CATATTTCGG CATAAAATGG CAAATGCCCT 800

TGATTCTTGG AGGCATAAAT ATATTACAAT TTTGACCTGA ACTCAGACGT

$26 \mathrm{~S}$

\begin{tabular}{|l|l|}
\hline GATTACCTGC TGAACTTAAG CATATCAGTA AGCAGAGGAA AAGAAACTAA & 900 \\
CAAGGATTCC CTTAGTAACG GCGAGTGAAA
\end{tabular}

Fig. 1. Schematic diagram and nucleotide sequences of rDNA. The P. penetransspecific primers PP1 and PP2 were selected from ITS1 and ITS2 regions, respectively. Underlined sequences indicate PP1 and PP2. The coding region of 3 ' end of the $18 \mathrm{~S}$ and the $5.8 \mathrm{~S}$, and 5 ' end of the $26 \mathrm{~S}$ are outlined. 
ampicillin medium containing X-Gal and IPTG. Plasmid DNA was prepared by the SDS-alkaline lysis method and purified by precipitation with polyethylene glycol (17). Plasmid DNA templates were sequenced on both strands with the dye-primer cycle using an Applied Biosystems 373A DNA sequencer (Perkin-Elmer). The sequences were analyzed using DNASIS software (Hitachi Software Engineering).

Development of $\mathrm{P}$. penetrans-specific primers

Based on the ITS1 and ITS2 sequences, a primer set was designed and designated as the primers PP1 and PP2 specific for P. penetrans (Fig. 1). These primers were synthesized by BRL Life Technologies, Inc. PCR amplification of DNA obtained from seven Pratylenchus species was performed using these primers and AmpliTaq Gold (Perkin-Elmer). An initial preincubation step at $95^{\circ} \mathrm{C}$ for $12 \mathrm{~min}$ was followed by 40 cycles at $95^{\circ} \mathrm{C}$ for $30 \mathrm{~s}$ and at $66^{\circ} \mathrm{C}$ for $30 \mathrm{~s}$, and finally incubated at $72^{\circ} \mathrm{C}$ for $5 \mathrm{~min}$.

\section{RESULTS}

Irrespective of a combination of the primers examined (18S and 26S, $18 \mathrm{~S}$ and $5.8 \mathrm{~S} \mathrm{R}$, and $5.8 \mathrm{~S}$ F and 26S), PCR amplification produced a single fragment for every Pratylenchus species examined, although the length of the ITS regions from purified genomic DNA were slightly different among the species (Fig. 2A-C).

The sequence alignments of $P$. penetrans was consisted of $290 \mathrm{bp}$ from the ITS1 and $189 \mathrm{bp}$ from the ITS2 (Fig. 1). The PCR primers, PP1 and PP2, were successfully designed based on the

A

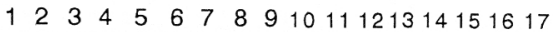

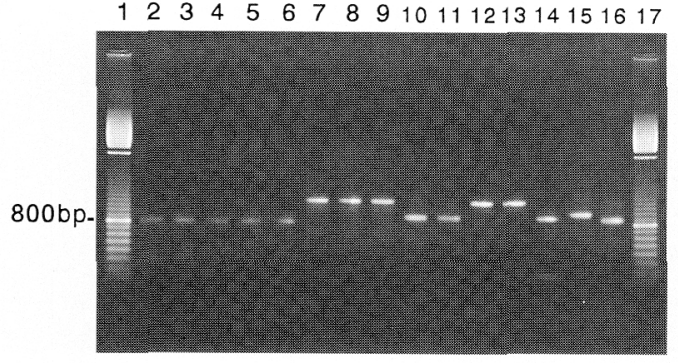

C

12234456678891011121314151617

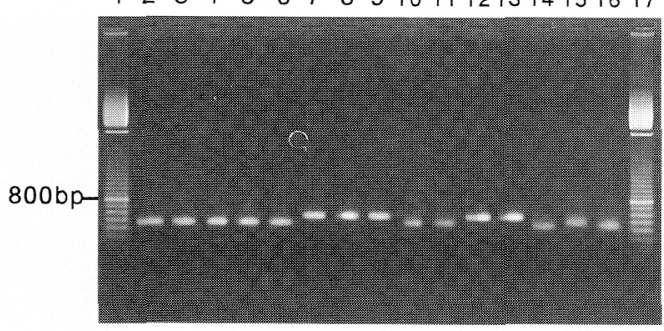

B

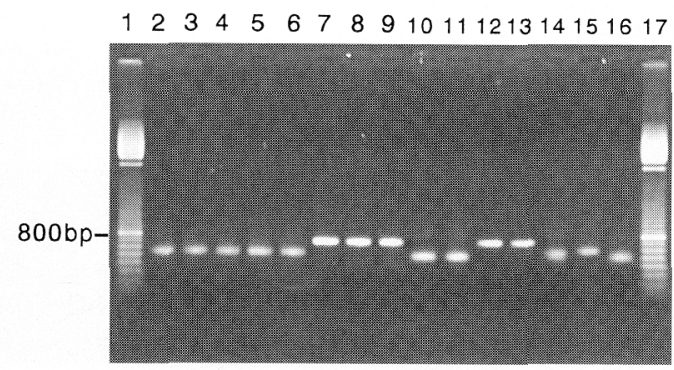

D

12234456678891011121314151617

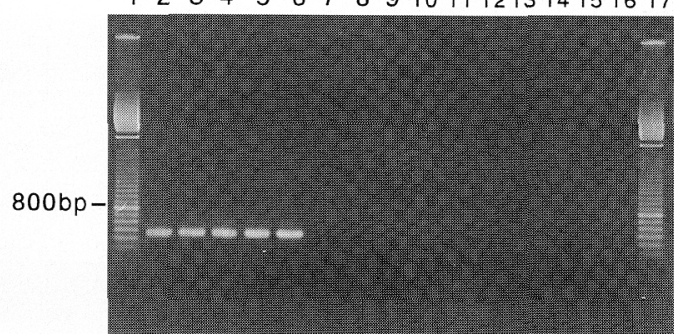

Fig. 2. PCR profile obtained by using four different combinations of primers: A, 18S / 26S; B, 18S / 5.8S R; C, 5.8S F / 26S; D, PP1 / PP2. Lanes 1 and 17, 100 bp ladder; lanes 2 to 16, PH2, PI, PC, PA, PS, CI, CN, CKU, VSA, VS1, LS1, LS2, BO, CH1, and ZK. Refer Table 1 for the explanation of these codes. 


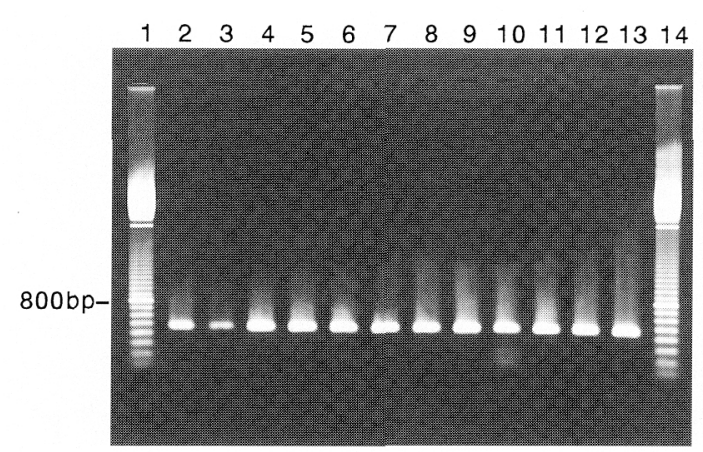

Fig. 3. Detection of DNA amplified from a single individuals of $P$. penetrans in different developmental stages. Lanes 1 and 14, 100 bp ladder; lanes 2 to 4 , second stage juvenile; lanes 5 to 7 , fourth stage juvenile; lanes 8 to 10 , male adult; lanes 11 to 13 , female adult.

ITS1 and ITS2 sequences of $P$. penetrans, respectively. These primers had 50\% or higher GC content and lacked in an obvious secondary structure. The PP1 sequence was 5'-ATGATGGAAGTGTCCGCCT-3' and the PP2 was 5'-CCCAACGACGGTCAAAAGG-3'. These primers did not amplify any purified genomic DNA from P. coffeae, P. vulnus, P. loosi, P. crenatus, $P$. brachyurus and $P$. zeae, but did a 462 bp fragment from the purified genomic DNA of the seven tested isolates of $P$. penetrans (Fig. 2D). Essentially the same result was obtained when the crude lysates of these Pratylenchus species were used as DNA templates. The primers, PP1 and PP2, amplified the $462 \mathrm{bp}$ fragment too from a single individuals of the second- and fourth-stage juveniles and of male and female adults of P. penetrans (Fig. 3).

\section{DISCUSSION}

In the genus Pratylenchus, $P$. penetrans is one of the best known species which distributes widely $(5,13)$ and damages a wide variety of crops. For a successful crop management, accurate identification of $P$. penetrans is critically important. The morphological characteristics, which are used to separate $P$. penetrans from other species in the same genus, are variable even in a population originating from a single gravid female (22). In order to identify $P$. penetrans, we developed a simple and efficient method which was realized by the use of the species-specific two primers for PCR.

Eukaryotic ribosomal DNA contains two internal transcribed spacers (ITS1 and ITS2) which separate the three mature rRNA sequences (5.8S, $18 \mathrm{~S}$, and $26 \mathrm{~S}$ ). Sequence analyses of rDNA from diverse organisms revealed highly conserved sequences in the rRNA genes and highly variable ones in the ITS (9). In fact, the sequences of the rRNA and of the ITS of $P$. penetrans were similar to and considerably different from those of the other Pratylenchus species, respectively (6). Consequently, our ITS sequence-based primers for PCR amplified the P. penetransspecific fragments.

Restriction pattern of the amplified ITS regions have been compared to discriminate nematode species $(10,14,20,23,24,26)$. However, restrictive digestion of the amplified products is too laborious. Contrarily, the method we developed is simple and easy, since agarose gel electrophoresis alone is required after PCR. Recently a random amplified polymorphic DNA 
(RAPD) analysis has been employed to discriminate nematode species $(4,25)$, but its reproducibility is a subject of discussion. Many researchers are seeking for species-specific probes which yield reliable results. The method we developed in the present study is easy and reliable for the identification of $P$. penetrans juveniles and adults at organismic level.

\section{ACKNOWLEDGMENTS}

We thank Mr. H. Yoshida, Mr. K. Saito and Dr. A. Kato, Hokkaido National Agriculture Experiment Station, for their useful suggestions, Mr. M. Yoshida, National Institute of AgroEnvironment Science, for his technical advice, and Dr. R. Takahashi and Dr. J. G. Dubouzet, Hokkaido National Agriculture Experiment Station, for critical reading of the manuscript.

\section{LITERATURE CITED}

1) BAum, T. J., LEwIS, S. A. \& DEAn, R. A. (1994) Isolation, characterization, and application of DNA probes specific to Meloidogyne arenaria. Phytopathology 84, 489-494.

2 ) Burrows, P. R. \& PERry, R. N. (1988) Two cloned DNA fragments which differentiate Globodera pallida from G. rostochiensis. Rev. Nematol. 9, 441-445.

3 ) Castagnone-Sereno, P., Esparrago, G., Abad, P., Leroy, F. \& Bongiovanni, M. (1995) Satellite DNA as a target for PCR-specific detection of the plant-parasitic nematode Meloidogyne hapla. Curr. Genet. 28, 566-570.

4 ) Cenis, J. L. (1993) Identification of four major Meloidogyne spp. by random amplified polymorphic DNA (RAPD-PCR). Phytopathology 83, 76-80.

5 ) ChiKaOKa, I. (1983) Studies on damage of crops by the root lesion nematode, Pratylenchus penetrans COBB, and control measures especially by the utilization of marigold (Tagetes spp.). Bull. Agric. Res. Inst. Kanagawa Prefect. 125, 1-72. (in Japanese with English summary)

6 ) Ferris, V. R., Ferris, J. M., FAghini, J. \& Ireholm, A. (1994) Comparisons of isolates of Heterodera avenae using 2-D PAGE protein patterns and ribosomal DNA. J. Nematol. 26, 144-151.

7 ) Gотон, A. (1974) Geographic distribution of Pratylenchus spp. (Nematoda: Tylenchidae) in Japan. Bull. Kyushu Agric. Exp. Stn. 17, 139-224. (in Japanese with English summary)

8 ) Hensom, J. M. \& French, R. (1993) The polymerase chain reaction and plant disease diagnosis. Annu. Rev. Phytopathol. 31, 81-109.

9 ) Hills, D. M. \& Dixon, T. D. (1991) Ribosomal DNA: molecular evolution and phylogenetic inference. Q. Rev. Biol. 66, 411-453.

10) Ibrahim, S. K., Perry, R. N., Burrows, P. R. \& Hooper, D. J. (1994) Differentiation of species and populations of Aphelenchoides and of Ditylenchus angustus using a fragment of ribosomal DNA. J. Nematol. 26, 412-421.

11) Ibrahim, S. K., Perry, R. N. \& WebB, R. M. (1995) Use of isoenzyme and protein phenotypes to discriminate between six Pratylenchus species from Great Britain. Ann. appl. Biol. 126, 317-327.

12) Jatala, P. \& Berge, J. (1990) Nematode parasites of root and tuber crops. In: Plant Parasitic Nematodes in Subtropical and Tropical Agriculture (Luc, M., SIKORA, R. A. \& BRIDGE, J., eds.), CAB International Institute of Parasitology, 137-180.

13) Jenkins, M. R. \& Taylor, D. P. (1967) Plant Nematology, Reinhold, New York, 68-77.

14) Joyce, S. A., Burnell, A. M. \& Powers, T. O. (1994) Characterization of Heterorhabditis isolates by PCR amplification of segments of mtDNA and rDNA genes. J. Nematol. 26, 260-270.

15) Krusberg, L. R. \& Blickenstaff, M. L. (1964) Influence of plant growth regulating substances on reproduction of Ditylenchus dipsaci, Pratylenchus penetrans, and Pratylenchus zeae on alfalfa tissue cultures. Nematologica 10, 145-150.

16) Piotte, C., Castagnone-Sereno, P., Bongiovanni, M., Dalmasso, A. \& Abad, P. (1995) Analysis 
of a satellite DNA from Meloidogyne hapla and its use as a diagonostic probe. Phytopathology 85, 458-462.

17) Maniatis, T., Fritsch, E. J. \& Sambrook, J. (1989) Molecular Cloning. A Laboratory Manual, 2nd Edition, Cold Spring Harbor, New York.

18) Marchuk, D., Drumm, M., Saulno, A. \& S. Collin, F. (1991) Construction of T-vectors, a rapid and general system for direct cloning of unmodified PCR products. Nucleic Acids Research 19, 1154.

19) Mizunubo, T. (1992) The classification, morphology and distribution of the genus Pratylenchus in Japan. In: Progress in Nematology (NAKAsono, K., ed.). Jpn. Nematol. Soc., Tsukuba, 40-47. (in Japanese)

20) ORUI, Y. (1996) Discrimination of the main Pratylenchus species (Nematoda: Pratylenchidae) in Japan by PCR-RFLP analysis. Appl. Entomol. Zool. 31, 505-514.

21) Tares, S., Lemontey, J. M., De Guiran, G. \& Abad, P. (1994) Use of species-specific satellite DNA from Bursaphelenchus xylophilus as a diagnostic probe. Phytopathology 84, 294-298.

22) TARte, R. \& MaI, W. F. (1976) Morphological variation in Pratylenchus penetrans. J. Nematol. 8, 185-195.

23) Vrain, T. C., Wakarchuk, D. A., Levesque, A. C. \& Hamilton, R. I. (1992) Intraspecific rDNA restriction fragment length polymorphism in the Xiphinema americanum group. Fundam. appl. Nematol. 15, 563-573.

24) Wendt, K. R., Vrain, T. C. \& Webster, J. M. (1993) Separation of three species of Ditylenchus and some host races of $D$. dipsaci by restriction fragment length polymorphism. J. Nematol. 25, 555-563.

25) Xue, B., Baillie, D. L. \& Webster, J. M. (1993) Amplified fragment length polymorphisms of Meloidogyne spp. using oligonucleotide primers. Fundam. appl. Nematol. 16, 481-487.

26) Zijlstra, C., Lever, A. E. M., Uenk, B. J. \& Van Silfhout, C. H. (1995) Differences between ITS regions of isolates of root-knot nematodes Meloidogyne hapla and M. chitwoodi. Phytopathology 85, 1231-1237.

Accepted for publication: March 30, 1997.

\section{和文摘要}

\section{種特異的プライマーを用いたキタネグサレセンチュウの同定}

\section{植原 健人・水久保隆之・串田 篤彦・百田 洋二}

キタネグサレセンチュウのPCR法による同定を目的として、種特異的プライマーの作成を試みた。 まず、rDNAのITS領域の塩基配列を決定し、ITS1およびITS2の塩基配列に基づいて、プライマーPP1 およびPP2を作成した。この 2 つのプライマーを用いて、Pratylenchus属線虫 7 種のDNAを鋳型とし てPCRを行ったところ、キタネグサレセンチュウでのみ $462 \mathrm{bp} の$ 種特異的な増幅産物が得られた。同 一の増幅産物は、実験に供したキタネグサレセンチュウの 7 地域個体群からも得られた。このプライ マーセットを用いた検出精度は高く、1 頭の 2 期幼虫、 4 期幼虫、雄成虫または雌成虫から抽出した DNAを用いてPCRを行った結果、いずれの発育ステージからも種特異的な増幅産物が得られた。以上 の結果より、本実験で用いた一対のプライマー(PP1とPP2) は、キタネグサレセンチュウの同定に有 効と結論された。 